\title{
Interactive comment on "Sedimentary ancient DNA and pollen reveal the composition of plant organic matter in Late Quaternary permafrost sediments of the Buor Khaya Peninsula (north-astern Siberia)" by Heike Hildegard \\ Zimmermann et al.
}

Heike Hildegard Zimmermann et al.

heike.zimmermann@awi.de

Received and published: 12 December 2016

We would like to thank Dr. Rudaya for her thoughtful comments and suggestions which will improve the clarity and the quality of the paper.

We uploaded our responses in the form of a supplement. 
http://www.biogeosciences-discuss.net/bg-2016-386/bg-2016-386-AC2supplement.pdf

Interactive comment on Biogeosciences Discuss., doi:10.5194/bg-2016-386, 2016. 